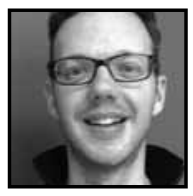

\title{
Lest We Forget: Mixing Traditional and Digital Learning in the History Classroom
}

\author{
Matthew Russell, D’Arcy McGee High School
}

\begin{abstract}
This paper presents an experience of integrating digital technology with traditional historical research in a grade 11 history classroom. Students researched First World War soldiers from western Quebec using online databases and archival sources and presented their research using a Wordpress blog and Google Earth. Students built their sense of historical consciousness by connecting to the past of their community and developing disciplinary skills such as using primary sources. Throughout the project, students were engaged in the authentic task. The success of the project indicates that teachers should be encouraged to use more digital technology in the history classroom.
\end{abstract}

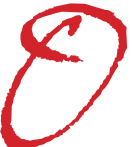

n May 3, 1915 Captain James Ross, a medical officer with the 3rd Brigade, Canadian Field Artillery wrote, "First of all we could see the air get green above the trenches, then firing started and then we opened up. They shelled us pretty heavily at the battery, but did very little damage," (Ross, 1915). The Germans had gassed the Canadian positions at St. Julien in the Ypres sector of Belgium. Although the 3rd Brigade might have been spared the worst of it, the 1st Brigade Canadian Field Artillery was mauled that day. The unit's War Diary, the official record of its actions and movements, stated that it endured an intense enemy barrage and was reduced to forming composite batteries from its twelve remaining guns. During the shelling, Lieutenant Alexis Helmer from Hull, Quebec was killed (1st Brigade Canadian Field Artillery, War Diary, 1915). 
Who was Alexis Helmer? Who were the other men, and some women, from western Quebec who enlisted in the Canadian Expeditionary Force (CEF) during the First World War? What was their war experience like? How can we honour their service and sacrifice? The Western Quebec Soldier's Stories project is an attempt to answer these questions. The project was about students melding the traditional practices of the historian with digital research and using new digital technologies like online databases, blogs, and Google Earth to develop and expand upon historical thinking skills. Historical thinking skills are seen as the disciplinary methods that are employed by historians practicing their craft. Abilities such as using evidence, chronology, cause and consequence, continuity and change, and historical empathy fall under the rubric of historical thinking skills (Seixas, 2006; Wineburg, 2001).

This project has its origin in the work of another teacher. Blake Seward, a history teacher in Smiths Falls, Ontario was intrigued by the names on the local cenotaph. He set out with his students to explore and to document the war experiences of these soldiers. His "Lest We Forget Project" has spread nationally with the help of Library and Archives Canada (LAC), and now the Canadian War Museum (CWM).

This paper will discuss how in our classroom, we moved from traditional paper research and writing, to sharing the war stories of the men and women of our community using new technology. In doing so, our students engaged in the work of historians in researching and writing, but used the web to communicate in both written and visual form using WordPress and Google Earth. Through this process the students developed their sense of historical consciousness by researching their own community.

The students in Smiths Falls had names on their cenotaph as a starting point; however, in Aylmer we did not. Despite the lack of individual recognition on the war memorial, the names of those who served in the First World War are still able to be found. A visit to the local Anglican Church gave a number of names on the honour roll. A search of the nominal rolls (lists of soldiers on embarkation to Europe) of local units like the 38th Battalion also yielded a number of results. As well as these traditional research methods, a search of online databases like the Canadian Virtual War Memorial (http://www.veterans.gc.ca/eng/collections/virtualmem) and the Canadian Great War Project (http://www.canadiangreatwarproject.com) also proved fruitful. Combined there are possibly hundreds of stories of soldiers and nursing sisters from Western Quebec to be told. 
The next step was to discover more about a particular soldier. In Canada, the records of soldiers from the First World War are held by LAC. They are in the process of being digitized, but a portion of the files are freely accessible on the LAC website. The scanned documents are the attestation papers that were filled out for (or by) the man when he enlisted in the CEF. The database is searchable by the soldier's name or regimental number and leads the viewer to a GIF copy of their attestation paper. Students were each assigned a regimental number and asked to go to the database and bring in a copy of the attestation paper of their soldier or nurse. I used my own great grandfather as a model and demonstrated the steps involved in finding the attestation papers.

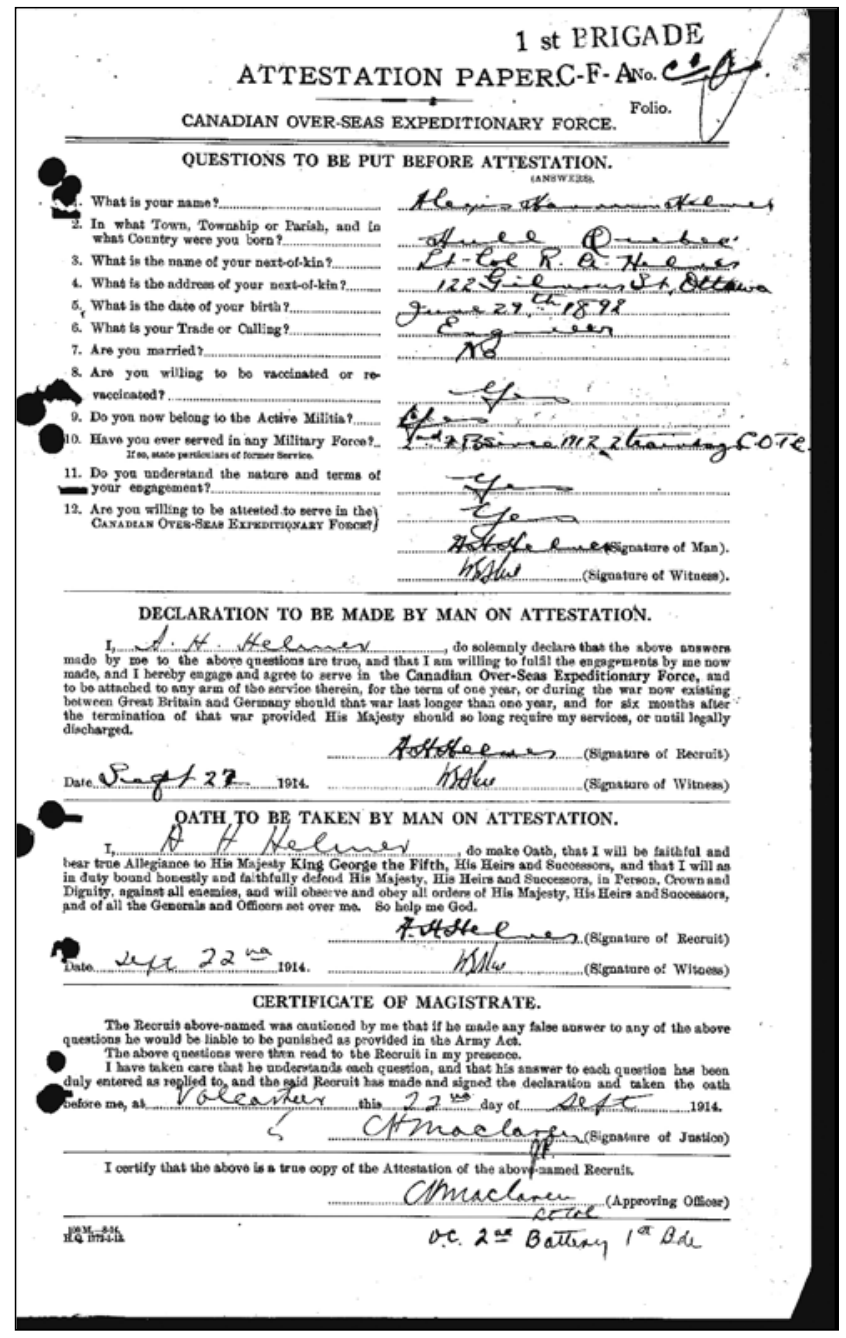

Fig. 1: Attestation form 
The information researched from the Attestation Forms allowed the class to determine the socioeconomic make-up of the soldiers that they are studying. For example, Alexis Helmer's form states that he was single, an engineer, had prior military experience in the militia and was the son of a Lieutenant-Colonel. Alexis Helmer appears to be middle class-but were all soldiers middle class? John Sheahan was a chemical tester. Ferdinand Leon, conscripted into the CEF, was a labourer (Helmer, Sheahan, Leon, Attestation Forms). Was there a class difference between English and French soldiers from this area? Taken together, the attestation forms allow the class to make inferences about what the community was like almost a hundred years ago. As well, the individual student can begin to form a mental picture about the soldier as the forms also contain a rudimentary description of the man. We know that Alexis was blue eyed, fair haired, and had a scar on his left leg (Helmer, Attestation Form).

After analyzing the attestation papers, the class members were ready to go to the Canadian War Museum to see the rest of their soldier's file. The students were given an introduction to the different types of documents found in a soldier's file by museum staff. What followed was total immersion for the next two hours. Time flowed as the students were transported back in time and learned about the journey of their soldier.

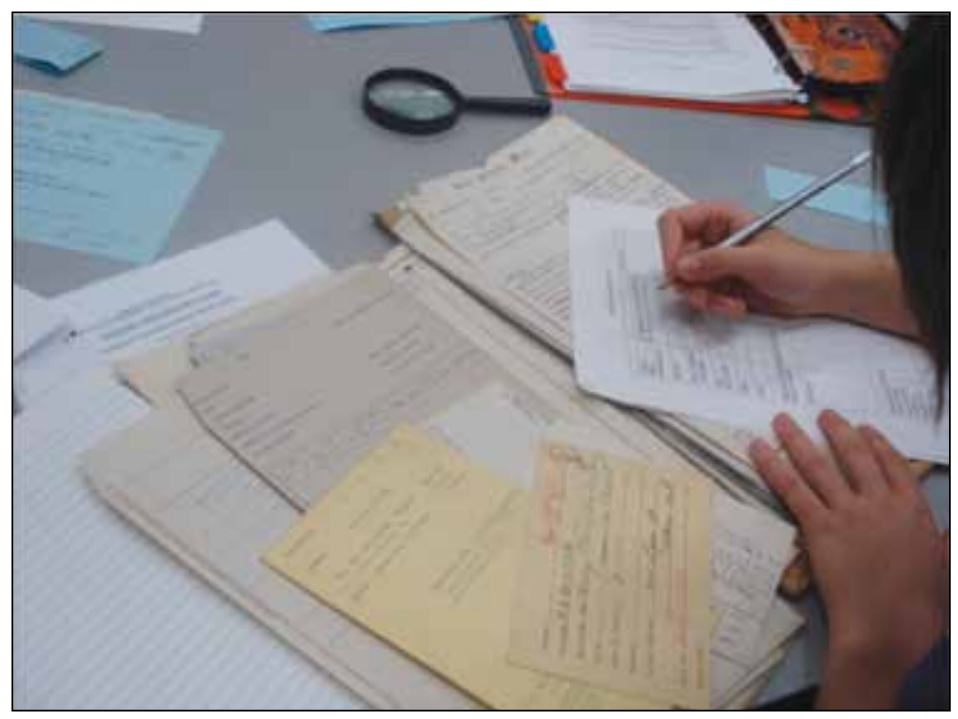

Fig. 2: Analyzing primary source documents 
Among the documents that were analyzed were casualty forms and the record of service. These two forms serve as the foundation for the students' research. The record of service was created at headquarters and is generally more legible, while the casualty form was created by the soldier's unit often while he was at the front. The title "casualty form" is a misnomer as it not only documents a soldier's injuries, but also some movements that the soldier went through. These forms begin with the embarkation to Britain from either Quebec or Halifax and list the ship that the unit sailed on. What usually follows is where the ship arrived in port and then where the unit went for training in England. Any changes in the unit that the soldier was affiliated with are also listed on the form. When the unit was transferred to the front was also noted and all further notations are vaguely listed as being from either "the field" or France. The casualty forms will note if the soldier went on leave, fell sick, or violated discipline which usually resulted in Field Punishment no. 1-being tied to a fence post or other fixed object for two hours a day and then subjected to hard labour. Gunshot wounds, lacerations, and other injuries were listed along with the process of the wounded soldier as he was transferred from field ambulance to casualty clearing station to general hospital. The forms may also record the soldier's ultimate fate if he died during the war. By examining the files, the students participated in the actual work of historians-looking at the fragmentary record of the past and trying to re-assemble the pieces.

Although the casualty form and the record of service offer a lot of insight into the movement and experience of a soldier, they do not give any indication of what the soldier went through while in the trenches of France and Flanders. For this information we needed to cross-reference with the unit War Diary. The War Diaries are available electronically from the LAC website. One can search for a particular unit, but the entries in the War Diaries are not searchable, nor are they necessarily organized in a chronological way. Furthermore, some units had similar names, particularly artillery units. Because of the overwhelming amount of information, some students find this step particularly onerous (Lee, 2002). Despite this barrier, the War Diaries provide an excellent source of information. While some Diaries were rudimentary in the description of event, others had officers that wrote with a narrative flair. According to historian Tim Cook (2006), the quality of the War Diaries greatly improved following the intervention of the Canadian War Record's Office, which wanted to have material for the official history of the war. The Diaries are also a great source for official orders and maps that were deposited in the appendices. By cross-referencing a soldier's file with a war Diary we are able to find out that Lt. Alfred Rimmer of Aylmer, Quebec was attached to the 1st Battalion and was at Mount Sorrel when he died in "intense bombardment of our whole area" (War Diary, June 1916, 1st Battalion CEF, p. 5). 
He was not the only one, as one hundred other men were either killed or wounded in the German shelling that June.

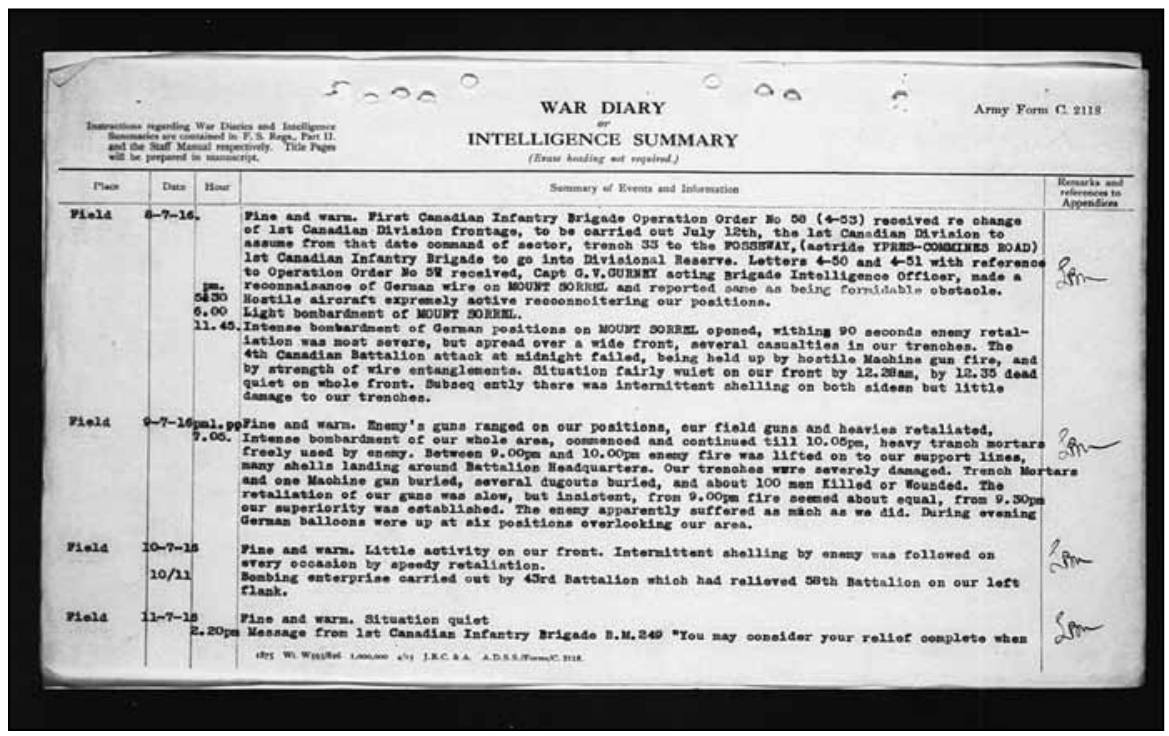

Fig. 3: War diary

What to do with all of this information? I had previously asked students to write a narrative essay describing a soldier's war service. Last school year, I wanted to try something new by incorporating new technologies into the history classroom, which according to Lévesque (2008) has not been done often in the past. I thought that it would be interesting if we could somehow map out a soldier's experience using Google Earth. Working with Paul Rombough of LEARN (www.learnquebec.ca) who set up a WordPress blog and wrote a script that allowed students to easily transfer the information from the blog entry to Google Earth, students plotted the movements of their soldiers across the globe. This gave the project two new dimensions. One was sharing their research in a real-world medium, and the other was the special context of seeing exactly where their soldier went.

The blog (western-quebec-soldiers.com) was loosely inspired by the posting of letters from the Trenches of Pte Harry Hamlin, 90 years after he had originally written them (WW1 Experiences of an English soldier). The students were asked to write a post for each major movement of their soldier. Most took to the assignment quite easily, but some had difficulty with the technical side of making blog posts or linking to Google Earth. But with some coaching by Paul, they were able to overcome these small obstacles. Overall the students were once again completely engaged in 
the task. Paul supplied laptops for the students and we spent an afternoon in the school library working on the blog entries. Many of the entries include pictures or maps to provide extra context. The students also cross-referenced the entry to a "pin" that they had placed in Google Earth. This allowed the students to make a virtual tour of their soldier's progress from western Quebec, to training in Canada, to Halifax for embarkation, to training in England, and finally to France or Flanders. It was revealing to see just how far some of these men went.

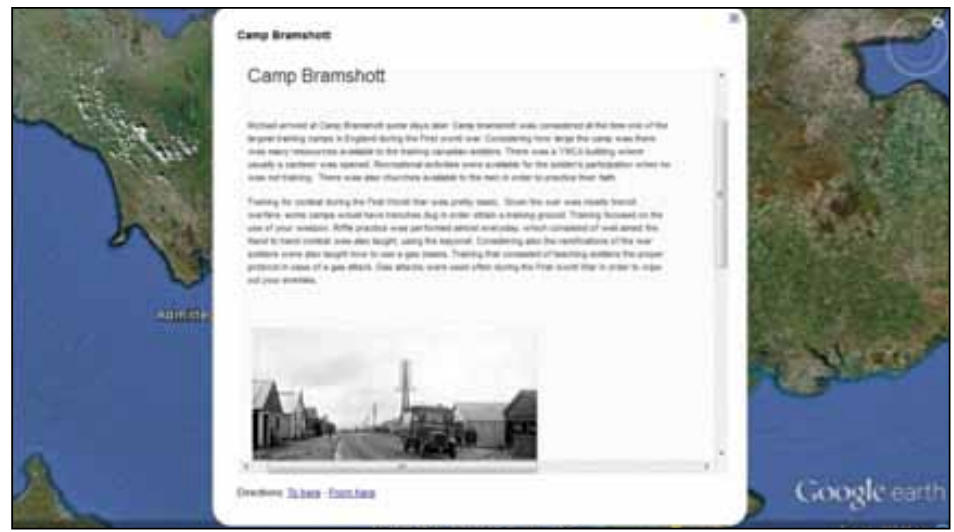

Fig. 4: Screenshot Google earth

Throughout the project it was interesting to see that the students would take ownership of the person that they were researching. They would refer to them as "my soldier" or "my guy." Some would go and try to visit the address on the attestation form, or use Google street view to see where they had lived. Many openly wondered what became of their families? Did they have children? Or if their soldier had survived the war, what happened to them? These questions were left unanswered, but they underlined the developing historical consciousness of the students. They realized that these men and women were individuals who had lives and families much like their own. The people in the past lived in this community, walked the same streets, and lived in the houses around the corner. Their soldier had become the face of the First World War.

Overall, the project was a success. Students were engaged throughout the entire process. The experience allowed students to practice disciplinary skills like analyzing primary sources, and developing historical empathy towards the soldiers and nurses that lived in the past. They also combined older research methods like handling historical artifacts and documents, and using newer technologies like databases and scanned documents. The students expressed their research in an authentic 
way by creating their blog posts and mapping out the soldier's journey using Google Earth. Lest We Forget has ensured that these students will never forget the people of their community who answered the call to duty almost one hundred years ago.

\section{References}

Cook, T. (2006). Clio's warriors: Canadian historians and the writing of the world wars. Vancouver: UBC Press.

Helmer, A. (1914). Attestation Form. Library and Archives Canada, Ottawa, ON. Retrieved from http://data2.archives.ca/cef/gpc006 /385066a.gif

Lee, J.K. (2002). Digital History in the Social Studies/History Classroom. The History Teacher, 35, 503-517.

Leon, F. (1917). Attestation Form. Library and Archives Canada, Ottawa, ON. Retrieved from http://data2.archives.ca/cef/gpc009 /458806a.gif

Ross, J. (1915, May 3) [Letter to his family about war experience]. Retrieved from http:// www.canadianletters.ca/letters.php?lett erid $=3246 \&$ warid $=3 \&$ docid $=1 \&$ collectio nid $=202$

Seixas, P. (2006). Benchmarks of Historical Thinking: A Framework for Assessment in Canada. Retrieved from http://histori calthinking.ca/sites/default/files/Frame work.Benchmarks.pdf
Sheahan, J. (1917). Attestation Form. Library and Archives Canada, Ottawa, ON. Retrieved from http://data2.archives.ca/ cef/gat2/087900a.gif

War Diary, 1st Battalion Canadian Expeditionary Force. (1916). Library and Archives Canada, Ottawa, ON. Retrieved from http://data2.collectionscanada.ca/e/ e043/e001073720.jpg

War Diary, 1st Brigade Canadian Field Artillery. (1915). Library and Archives Canada, Ottawa, ON. Retrieved from http:// data2.collectionscanada.ca/e/e046/ e001146249.jpg

Wineburg, S. (2001). Historical thinking and other unnatural acts. Temple University Press: Philadelphia.

WW1 Experiences of an English Soldier. (n.d.). Retrieved from http://wwar1.blogspot.ca/

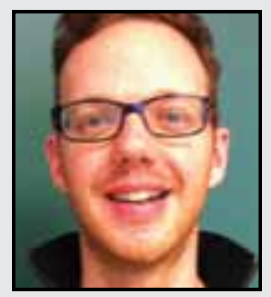

Matthew Russell is head of the social studies department at D'Arcy McGee High School in Gatineau, Quebec. He is interested in the development of historical thinking skills and the historical consciousness of young people. The Lest We Forget project and the memory of the men of the First World War are especially important to him. Matthew's great grandfather, Sapper Thomas Cameron, was wounded at Vimy Ridge and Passchendaele. 